\title{
Effect Of Number Of Pile In Pile-Raft System In Organic Clay
}

\author{
Dinachandra Thoidingjam ${ }^{1}$, Dr.D S V Prasad ${ }^{2}$, Dr. K.Rambha Devi ${ }^{3}$ \\ ${ }^{I}$ (PG Student, Department of Civil Engineering, BVC Engineering College, Odalarevu, Andhra Pradesh, India) \\ ${ }_{2}^{2}$ (Professor \&Principal, Dept. of Civil Engg., BVC Engineering College, Odalarevu,Andhra Pradesh, India ) \\ ${ }^{3}$ (Professor, Dept. of Civil Engineering, Manipur Institute of Technology Takyelpat, Imphal, India)
}

\begin{abstract}
In the valley area of Imphal in Manipur, organic clay are often encountered in the substrata of the soil which often creates problem in construction. These soils are characterized by low bearing capacity and high compressibility. A pile-raft foundation can be used to reduce the settlements caused by concentrated building loads. This study is mainly aimed to study the influence of spacing of piles and raft width on the behavior of the pile raft foundation in organic clay. Tests were conducted on rafts of size 100x100mm and $200 \times 200 \mathrm{~mm}$ of thickness $2 \mathrm{~mm}$. The numbers of piles were varied at 1,4 and 9 and from the test results the ultimate bearing capacity of Piles will be increased and the settlement of Pile is reduced as the diameter of Pile increases. It is obtained that the settlement in the pile group standing alone are fast in settling in the beginning and reduced after some loading, but in case of raft alone slow settlement is observed.
\end{abstract}

Keywords: Pile Raft System, Raft, Free Standing Pile Group, Area Ratio.

\section{Introduction}

In foundation engineering, generally the most popular types of foundations used for high rise buildings or special structures are raft foundations or pile foundations. These systems when implemented alone will fulfill the design requirements. However, in most cases they become over safe and economically not efficient. Furthermore, in some cases when being used alone they can cause some important problems. On the other hand, when the conditions are suitable, these systems can be combined and one can have a more efficient, safe and economical design. Thus, piled raft foundation system is one of those combined systems. Mat (raft) foundation on soft clayey soil shows maximum settlement, ultimately causes settlement of the huge building structure. In order to prevent this settlement, use of minimum number of piles below the raft improves the ultimate capacity, settlement and differential settlement of the foundation system. A piled raft foundation consists of three elements: the raft, the piles and the subsoil. The load is taken partly by the contact pressure between the raft and the soil and partly by the piles. The piles which is to be used as a settlement reducers .Piles in piled raft foundation can be used for two reasons: To reduce total settlement in rigid raft and to reduce total and differential settlement in flexible raft Cooke (1986) carried out experimental work on unpiled raft, free standing pile group and piled raft of different size in stiff clay and found that piled raft stiffness increases by $30 \%$ than that of free standing pile group. He also found that in case of rigid raft load sharing between piles in piled raft foundation depends on number of piles and spacing of piles.

\section{Review Of Literature}

Thakare.S.W and Pankaj Dhawale (2016), has conducted laboratory study on model piled raft foundation to evaluate the influence of configuration of piles and number of piles of piled raft foundation on ultimate bearing capacity and settlement reduction. In this laboratory study, three sets of model piled raft foundation were studied consisting of 16, 24 and 32 number of piles having 1/d ratio equal to 40 . In each sets, five different configurations of piles were tested. Pile diameter, pile length, type of soil and size of raft were kept constant. The results of the parametric study are presented and a result for an optimized configuration of piled raft is arrived at. The results of tests conducted on raft and piled raft foundation with different configurations of piles were compared in terms of ultimate bearing capacity, load sharing ratio and settlement reduction ratio. It is concluded that the configurations of piles in a piled raft foundation has significant effect on ultimate bearing capacity, settlement reduction and load sharing ratio between the raft and piles. Jaymin et al., (2016), has conducted experimental program includes the model test on unpiled raft, raft supported by single pile, $(2 \times 2)$ and $(3 \times 3)$ pile groups. The piles used in this test are non-displacement piles. The results of the tests show that as the number of piles underneath the raft increases from 1 to 9 piles, the load improvement ratio increases by 30-40\%, settlement reduction ratio increases by $18-90 \%$ and percentage of load carried by the raft decreases by $22-25 \%$. Also load improvement ratio is slightly increases by $1.5-5 \%$ and the settlement reduction ratio decreases by $1.5-30 \%$ as the raft-soil stiffness ratio increases for the given number of piles, while the load carried by the raft slightly decreases by $1.5-4.5 \%$ as the raft-soil stiffness increases. Nitin Nandwani et al., (2015), has studied on the use of piled raft foundations has become more popular in recent 
years, as the combined action of the raft and the piles can increase the bearing capacity, reduce settlement, and the piles can be arranged so as to reduce differential deflection in the raft. Piled raft foundation is a new concept in which the total load coming from the superstructure is partly shared by the raft through contact with soil and the remaining load is shared by piles through skin friction. A piled raft foundation is economical compared to the pile foundation. Because piles do not have to penetrate the full depth of clay layer but it can be terminated at higher elevations. Such piled raft foundation undergoes more settlement than the pile foundation and less settlement than the raft foundation. In this paper the study of different parameters like size of the raft, thickness of the raft, diameter of the piles, length of piles, spacing of pilesetc., which affect the behavior of piled raft foundation. And its interdependency is also reviewed for $G+20$ storey building. This study is useful to decide the various parameters required in the design of piled raft foundation and suggest the suitable combination of Pile Raft Foundation. Rautet al. (2015) conducted an experimental model to study the load sharing ratio behavior of piled raft foundation. The model tests were carried out on unpiled raft, raft supported by 4 piles and 16 piles. From the results of the study, it was concluded that the load sharing ratio of piled raft foundation depends on stiffness of pile and raft. Jaymin et al., (2014) has conducted an experimental program in laboratory to study the behaviour of piled raft foundation system subjected to vertical load. The experimental program includes the model test on unpiled raft, raft supported by single pile, $(2 \times 2)$ and $(3 \times 3)$ pile groups. The model piles used in this test are non displacement piles. In the laboratory test, model mild steel piles of diameter $10 \mathrm{~mm}$ and length $200 \mathrm{~mm}$ were used, represents slenderness ratio, L/D of 20 . The raft was made of mild steel plate with plan dimensions of $160 \mathrm{~mm} \times 160 \mathrm{~mm}$ with different thicknesses of $5 \mathrm{~mm}, 10 \mathrm{~mm}$ and $15 \mathrm{~mm}$. The results of the tests show that as the number of piles underneath the raft increases, load improvement ratio and settlement reduction ratio increase and percentage of load carried by the raft decreases and there is a negligible effect on load improvement ratio and settlement reduction ratio with increase in raft thickness, while raft thickness has a minimal effect on the load carried by the raft. Chaudhari and Dr K. N. Kadam(2013),. Has studied the influence of pile length configurations on behavior of multi-storied are evaluated under vertical loading. In practice, the foundation loads from structural analysis are obtained without allowance for soil settlements and the foundation settlements are estimated assuming a perfectly flexible structure. Hence, the interaction among structures, their foundations and the soil medium below the foundations alter the actual behaviour of the structure considerably than what is obtained from the consideration of the structure alone. In this work, analysis of pile soil structure interaction has been studied by finite element software ANSYS 11. Basuony et al., (2013), has conducted testing program includes tests on models of single pile, unpiled rafts and rafts on 1, 4, 9, or 16 piles. The model piles beneath the rafts are closed ended displacement piles installed by driving. Three lengths of piles are used in the experiments to represent slenderness ratio, $L / D$, of 20,30 and 50 , respectively. The dimensions of the model rafts are $30 \mathrm{~cm} \times 30 \mathrm{~cm}$ with different thickness of $0.5 \mathrm{~cm}, 1.0 \mathrm{~cm}$ or $1.5 \mathrm{~cm}$. The raft-soil stiffness ratios of the model rafts ranging from 0.39 to 10.56 cover flexible to very stiff rafts. The improvement in the ultimate bearing capacity is represented by the load improvement ratio, $L I R$, and the reductions in average settlement and differential settlement are represented by the settlement ratio, $S R$, and the differential settlement ratio, $D S R$, respectively. The effects of the number of settlement reducing piles, raft relative stiffness, and the slenderness ratio of piles on the load improvement ratio, settlement ratio and differential settlement ratio are presented and discussed. The results of the tests show the effectiveness of using piles as settlement reduction measure with the rafts. As the number of settlement reducing piles increases, the load improvement ratio increases and the differential settlement ratio decreases. Dr.G.Srilakshmi and Chethan Gowda R K(2012), has studied different piled raft configurations have been analyzed by two-dimensional plane-strain finite element analyses using ANSYS. In the study, raft dimensions, length and diameter of pile have been varied to find ultimate capacity of foundation under compression in sand. From the study it is observed that, settlement of foundation is decreasing with increase in diameter of piles where as ultimate capacity is increasing. Piled raft foundations having longer piles takes more load at higher values of settlements. Fioravante et al. 2010 conducted centrifuge test on piled raft foundation model to study the load transfer mechanism between the raft and the pile in sand soil and observed that load sharing mechanism is related to pile-soil stiffness.

\section{Soil Properties}

Organic clay used for the laboratory tests was collected from Imphal, Manipur, India as shown in the Fig.1, The organic clay found is black in colour with a foul smell. The organic clay is easily compressible and has an easily recognizable plant structures, there is a presence of fresh plant roots. The soil properties are obtained as below in table 1 
Table: 1Properties of Organic Clay

\begin{tabular}{|l|c|}
\hline Particulars & Details \\
\hline Type of Soil & Organic Clay \\
\hline Organic Content (OC \%) & 16.6 \\
\hline Water Content (w) (\%) & 112.6 \\
\hline Specific Gravity (Gs) & 1.67 \\
\hline Liquid Limit (LL) (\%) & 129 \\
\hline Plastic Limit (PL) (\%) & 62.16 \\
\hline Plasticity Index (PI or Ip) (\%) & 66.8 \\
\hline Liquidity Index (LI or IL) (\%) & 75.5 \\
\hline Consistency Index (Ic) (\%) & 24.6 \\
\hline
\end{tabular}

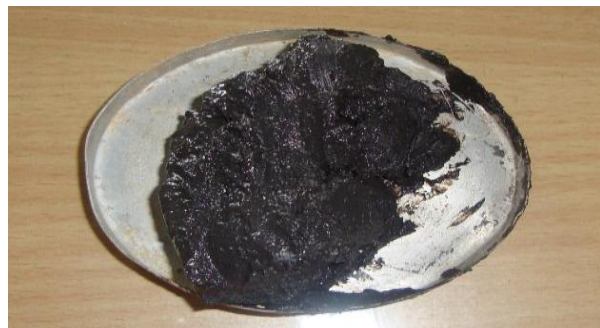

Fig. 1 Soil Sample Physical Appearance

\section{Experimental Study}

A loading frame (Fig.2) consists of beam and column was fabricated by using Channels sections of size ISC 300 having a height of $1500 \mathrm{~mm}$ and width of $1000 \mathrm{~mm}$. A loading system was built in it for load application. Consisting of channel section $150 \mathrm{~mm}$ as standing leg supported by the two channel section, one at the top of the base and another as the support in the mid of two legs which is made adjustable at for a gradual changes in height. Experiments were conducted on model pile raft (Fig.3) and free standing pile groups. Mild steel piles of uniform circular cross section of $10 \mathrm{~mm}$ diameter and length of $100 \mathrm{~mm}$ and $200 \mathrm{~mm}$ were used in the present investigation. Each pile was welded to the top on rafts made of mild steel square plates and the bottom was made into conical tips. The tests were conducted on artificially consolidated organic clay bed for determining load-settlement behavior in order to evaluate load carrying capacity of piled raft foundations as well as load sharing mechanism. The rafts used were of sizes $100 \times 100 \times 2 \mathrm{~mm}$ and $200 \times 200 \times 2 \mathrm{~mm}$. The numbers of piles were varied as 1, 4 and 9 such that the spacing and pile to raft area ratio (Rarea) between the piles were varied. Tests were also conducted on free standing piles of 1, 4, and 9 numbers keeping the spacing same as that for pile raft system. This was done to find the load share taken by the pile in the system. It is assumed that the load taken by the piles in the pile-raft system is same as that taken by free standing piles. The organic content of the soil was determined by finding the loss of ignition as per ASTM D 2974-87 guidelines. The organic content of organic clay is found to be $16.66 \%$.The organic clay was mixed with water and put in the test tank in layers. A layer of sand is put at bottom of the tank over which a thin cloth was laid to separate the layer of organic clay from the sand before putting the organic clay. At the top of the organic clay another cloth is put and then a layer of sand is put. Weights are placed over the sand layer to consolidate the organic clay (Fig.4) and kept for two days. At the end of two days the sand and cloth over was removed and tests are performed on the organic clay prepared

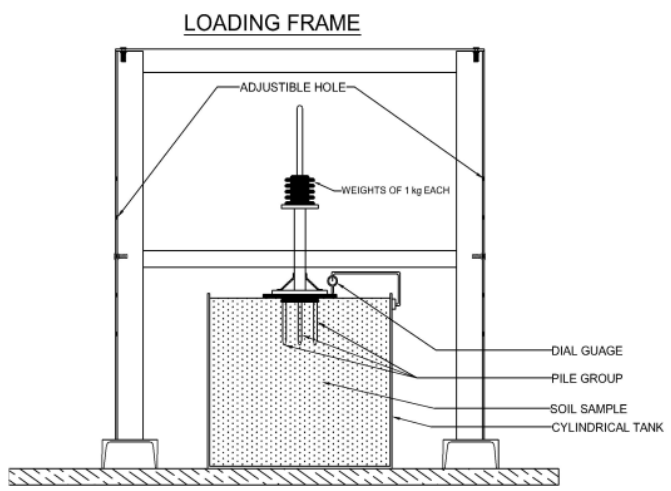

Fig.2 Pile Raft Model with Loading Arrangement 


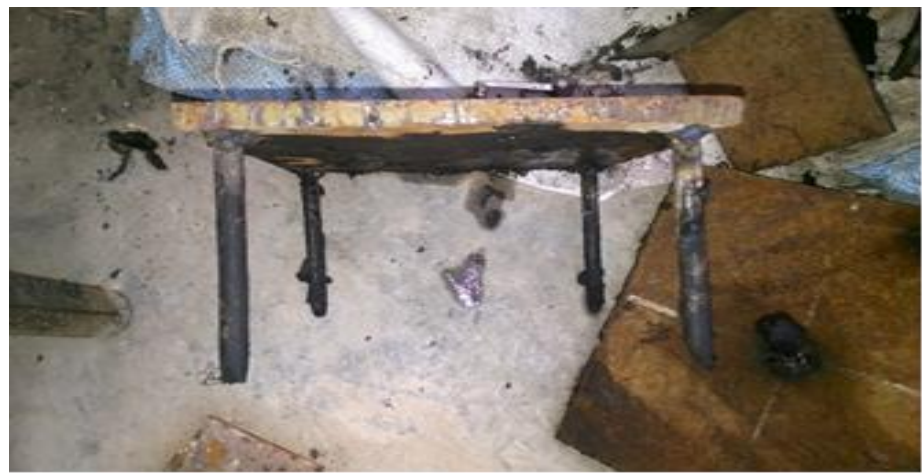

Fig.3: Model Pile Raft System

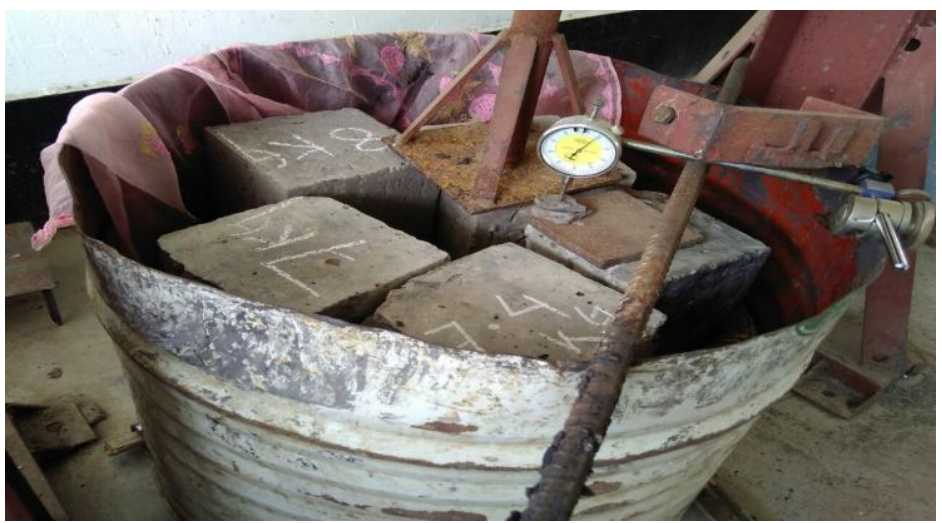

Fig.4 Consolidation of Organic Clay

Model pile raft system was pushed in the consolidated clay bed until the raft touched the organic clay top. It was ensured that while performing tests on piled raft and individual raft, there was a full contact between the soils layer and the raft. The organic clay was mixed with water and put in the test tank in layers. A layer of sand is put at bottom of the tank over which a thin cloth was laid to separate the layer of organic clay from the sand before putting the organic clay. At the top of the organic clay another cloth is put and then a layer of sand is put. Weights are placed over the sand layer to consolidate the organic clay (Fig.3) and kept for two days. At the end of two days the sand and cloth over was removed and tests are performed on the organic clay prepared. Model pile raft system was pushed in the consolidated clay bed until the raft touched the organic clay top. It was ensured that while performing tests on piled raft and individual raft, there was a full contact between the soil layer and the raft. The settlement was measured using two dial gauges having a $50 \mathrm{~mm}$ range with $0.01 \mathrm{~mm}$ sensitivity. They were placed diagonally opposite on the model raft to get average settlement at the center of raft. Loads were applied in gradual increment and settlements were recorded till there was no appreciable change in settlement for a particular load increment. Then the next load increment was applied. The tests were continued until the settlement was more than $10 \%$ of width of corresponding raft.

\section{Results And Discussions}

The Figs. 5 to 10 shows the load settlement curves with different number of piles and also the comparasion between different thicknesses for 100 and $200 \mathrm{~mm}$ width flexible and rigid piled rafts with 1,4 and 9 piles respectively. It is observed from these figures that the load carrying capacity of the piles increase as the size of the raft increase. The load vs. settlement curve for free standing piles with different area ratio (Rarea). Area ratio (Rarea) is defined as ratio of area of piles to area of raft expressed as percentage. It is observed that the piles with low area ratio settles faster than the with high area ratio. From the results of this study, the following conclusions can be drawn. It was obtained that the settlement in the pile group standing alone are fast in settling in the beginning and reduced after some loading, but in case of raft alone slow settlement is observed. The piles take a major portion of total load at the initial stage of loading, but after yielding, a considerable portion of total load is transferred by the raft. The settlement reduction ratio (immediate) of a piled raft decreases with increase in pile to raft area ratio as well as pile slenderness ratio. When the pile to raft area ratio decreases the settlement reduces, i.e. in the thesis pile to raft area ratio ranging from 28.26, 12.56, 7.07, 3.14 and 0.79 , the settlement reducing is decreasing from $28.26 \mathrm{p}$-r ratio to $0.79 \mathrm{p}-\mathrm{r}$ ratio. 


\section{Conclusions}

From the results of this study, the following conclusions can be drawn:

It has been observed that piled raft foundation concept has significant advantages in comparison to conventional foundation for some soft clay. The ultimate bearing capacity of Piles will be increased and the settlement of Pile is reduced as the diameter of Pile increases. It is obtained that the settlement in the pile group standing alone are fast in settling in the beginning and reduced after some loading, but in case of raft alone slow settlement is observed. The piles take a major portion of total load at the initial stage of loading, but after yielding, a considerable portion of total load is transferred by the raft. The settlement of raft depends on raft thickness; increasing the thickness of the raft the settlement reduction can be noticed. The settlement reduction ratio (immediate) of a piled raft decreases with increase in pile to raft area ratio as well as pile slenderness ratio. This analysis may be useful in design of piled raft in soft consolidating, organic, clayey soil. The settlement reduces when the slenderness ratio s/d reduces. The increases in number of piles in a piled raft foundation results in increase in ultimate bearing capacity and decrease in settlement.

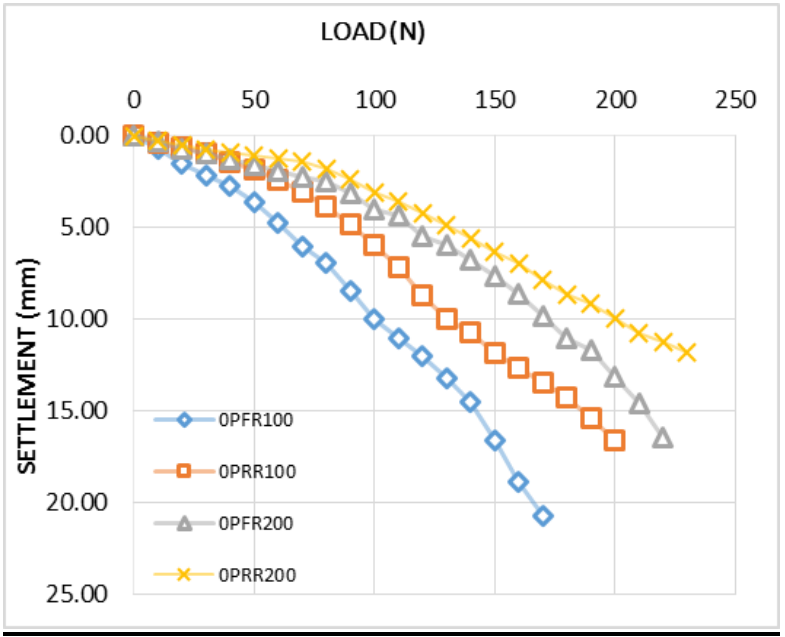

Fig.5 Load Vs. Settlement Curve with Raft Only (Without Pile)

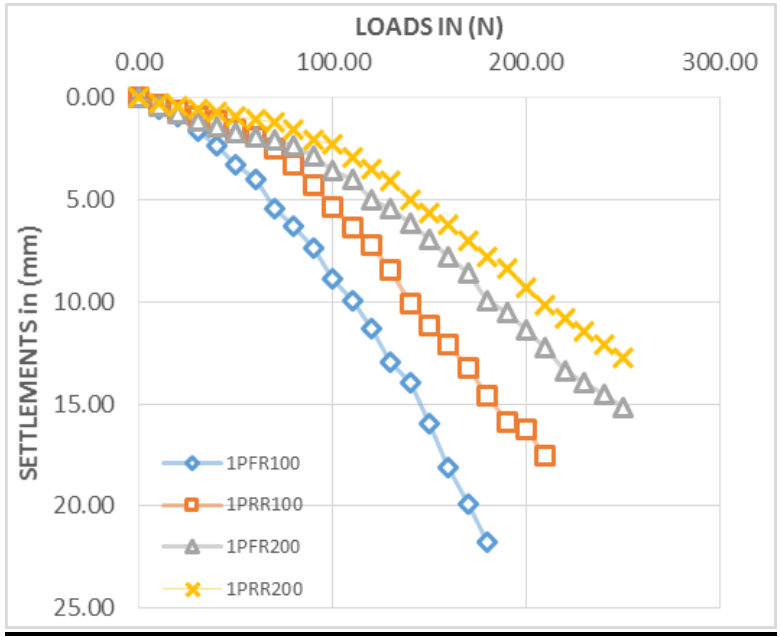

Fig.6 Load Vs. Settlement Curve with Raft only (with One Pile At The Center)

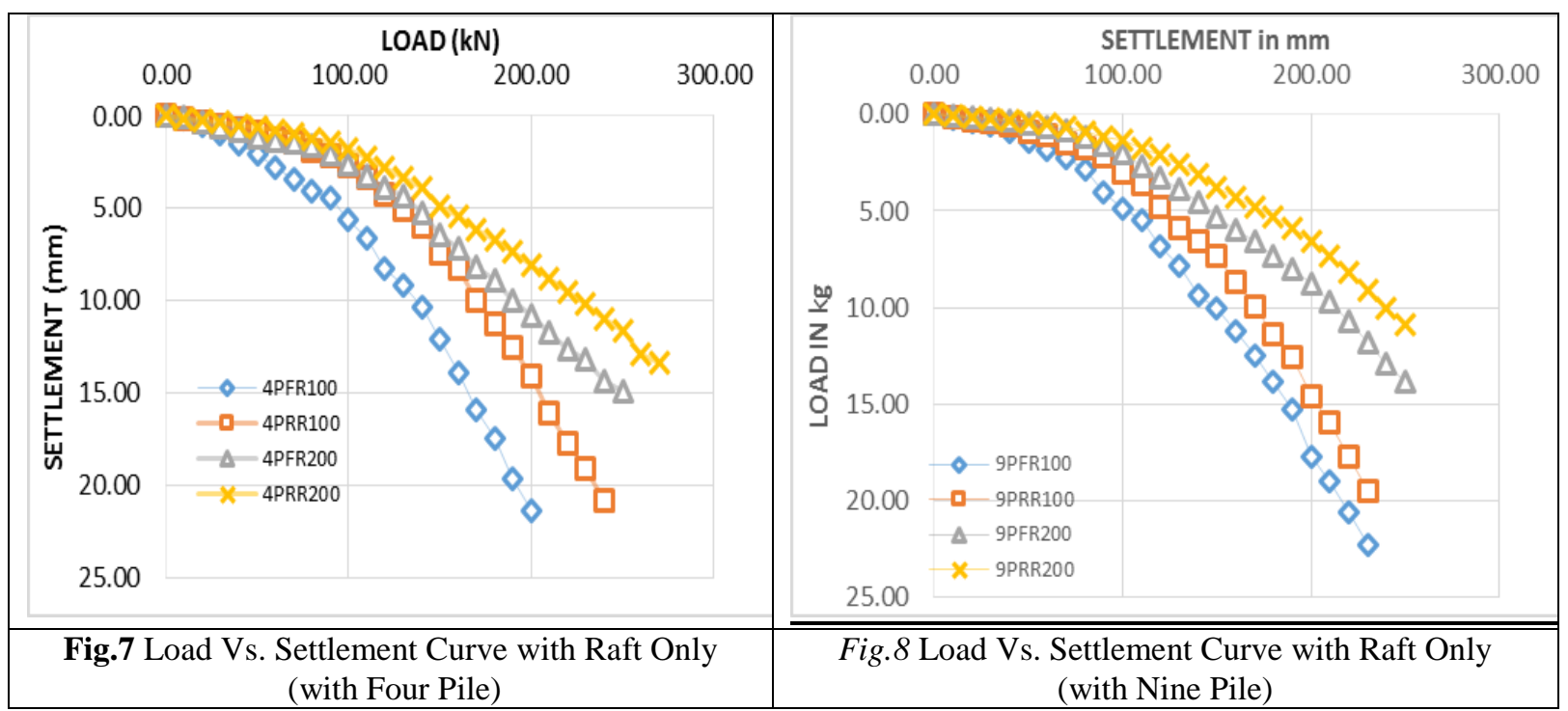



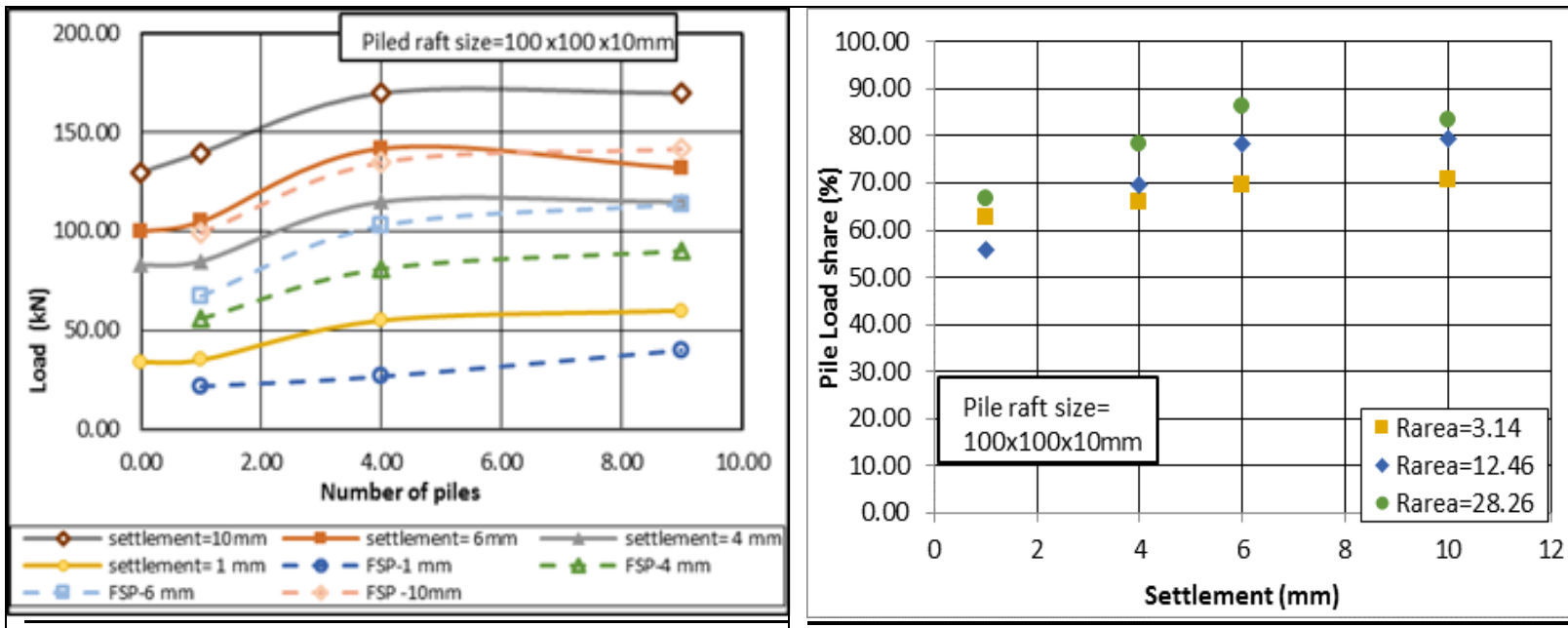

Fig.9 Comparison of Pile Raft Model Having 0, 1, 4 \&

9 Numbers of Piles and Variable Raft Thickness

Fig.10 Pile Load Share at Different Settlements of 100 Square Flexible Rafts

\section{References}

[1] Cooke, R.W. (1986). "Piled raft foundations on stiff clays: a contribution to design philosophy". Géotechnique, 36, No 2, 169-203

[2] Thakare.S.W, and Pankaj Dhawale(2016) "Performance of Piled Raft Foundation on Sand Bed" International Journal of Innovative Research in Science, Engineering and Technology,(An ISO 3297: 2007 Certified Organization), Vol. 5, Issue 6, June 2016

[3] Jaymin D. Patil, , Sandeep A. Vasanvala,, Chandresh H. Solanki(2016), “An Experimental Study on Behavior of Piled Raft Foundation "Indian Geotechnical Journal, volume 46,issue 1 pp.16-24.

[4] Raut J. M., Khandeshwar S. R. and Bajad S. P.,(2015), "Load Sharing Ratio of Piled Raft foundation", Proceeding of 50th Indian Geotechnical Conference, Paper No. 645, December 17-19, 2015.

[5] Nitin Nandwani, Prof P.J.Salunke, Prof N.G.Gore(2015), “Comparative Study Of Piled Raft Foundation" International Journal Of Engineering Sciences \& Research Technology, ISSN: 2277-9655, Namdwani, 4(11): November, 2015,pp.60-64.

[6] Jaymin D Patil, Sandeep A Vasanwala, Chandresh H Solanki (2014)," An Experimental Investigation On Behavior Of Piled Raft Foundation", International Journal of Geomatics and Geosciences Volume 5, No 2, 2014, ISSN 0976 - 4380, Pp.300-311.

[7] Basuony El-Garhy' Ahmed Abdel Galil, Abdel-Fattah Youssef, Mohamed Abo Raia (2013), "Behavior of Raft on Settlement Reducing Piles: Experimental Model Study "Journal Of Rock Mechanics And Geotechnical Engineering, Volume 5, Issue 5, Pp.389-399.

[8] R. R. Chaudhari, Dr K. N. Kadam(2013), "Effect Of Piled Raft Design On High-Rise Building Considering Soil Structure Interaction "International Journal Of Scientific \& Technology Research Volume 2, Issue 6, June 2013 ISSN $2277-861672$ Ijstr@2013.

[9] Dr.G.Srilakshmi, Chethan Gowda R K(2012)" Analysis of Piled Raft Foundation by Finite Element Method”, Non-Circuit Branches of the $3^{\text {rd }}$ Nirma University International Conference on Engineering (NUiCONE 2012).

[10] Fioravante V., and Giretti D.,(2010), Contact versus Noncontact Piled Raft Foundations, Canadian Geotechnical Journal, 47(11), pp 1271-1287. 